\title{
Inclusive practice and quality of education and care in the Dutch hybrid early childhood education and care system
}

\author{
W. M. van der Werf ${ }^{1 *}$, P. L. Slot ${ }^{1}$, P. N. Kenis ${ }^{2}$ and P. P. M. Leseman ${ }^{1}$
}

*Correspondence:
w.m.vanderwerf@uu.nl
${ }^{1}$ Utrecht University,
Heidelberglaan 1, 3584
CS Utrecht, The Netherlands
Full list of author information
is available at the end of the
article

${ }^{*}$ Correspondence: w.m.vanderwerf@uu.n

Utrecht University, CS Utrecht, The Netherlands

\begin{abstract}
The present study examined how in the context of the hybrid, privatized and marketized Dutch early education and care system (ECEC), childcare organizations respond to the public task of supporting inclusion and equity in an increasingly diverse society. Applying cluster analysis on the organizational characteristics of a nationally representative sample of 117 centers providing education and care for 0 - to 4-year-old children, three types of organizations were identified that differed strongly on cultural inclusion and observed quality in the classroom. Socially engaged (for-profit and notfor-profit) professional organizations served proportionally more children from low-SES and immigrant families, provided higher quality to these children, and were culturally more inclusive than both market-orientated and traditional professional-bureaucratic organizations. The findings are discussed with regard to the question how hybrid ECEC systems can be governed to optimally serve the public goals of inclusion and equity.
\end{abstract}

Keywords: Early childhood education and care, Privatization, System hybridity, Cultural inclusiveness, Process quality

\section{Introduction}

Diversity in socioeconomic status, ethnicity, culture, religion and language has grown rapidly in Western societies (Crul et al. 2013; Vertovec, 2007). Related to this, the divides between the rich and the poor, between the high and low-educated, and between main stream and cultural minority communities have become more visible and pervasive (Borgna and Contini 2014; Putnam 2015; Reardon 2011; Riederer and Verwiebe 2015; Rözer and Van de Werfhorst 2017). Traditional inequalities in educational and social opportunities between the lower and higher social classes have remained and are nowadays in some cases outflanked by new disparities relating to the cultural and linguistic background of ethnic minorities and newcomers to society. The Netherlands, despite a long tradition of social equity, tolerance, and cultural and religious pluralism, is not an exception to this (Driessen 2012; Kremer et al. 2014).

In the past decades, many countries, including the Netherlands, have initiated policies to combat educational inequality and to support the integration of immigrants and cultural minorities, focusing in particular on early childhood education and care (ECEC).

(c) The Author(s) 2021. This article is licensed under a Creative Commons Attribution 4.0 International License, which permits use, sharing, adaptation, distribution and reproduction in any medium or format, as long as you give appropriate credit to the original author(s) and the source, provide a link to the Creative Commons licence, and indicate if changes were made. The images or other third party material in this article are included in the article's Creative Commons licence, unless indicated otherwise in a credit line to the material. If material is not included in the article's Creative Commons licence and your intended use is not permitted by statutory regulation or exceeds the permitted use, you will need to obtain permission directly from the copyright holder. To view a copy of this licence, visit http://creativeco mmons.org/licenses/by/4.0/. 
This is based on the increasing evidence that use of high-quality ECEC reduces early developmental gaps (Leseman et al. 2017; Melhuish et al. 2015; Yoshikawa et al. 2013) and can have long-term economic benefits for society (Heckman 2011; Reynolds et al. 2011; Van Huizen et al. 2019).

There are, however, two complications. Concerns about the integration of immigrants and cultural minorities have in recent years led to a shift in the national integration policies of many countries, including the Netherlands, towards a stronger emphasis on assimilation, putting the national language and cultural customs, norms and values in the foreground in education in general and in ECEC in particular. This may jeopardize the sense of belonging of minority communities and their willingness to participate (Celeste et al. 2019; Malik 2015; Penninx 2008; Slot et al. 2018c; Ünver 2019). The second complication relates to the progressive privatization and marketization of national ECEC systems in the past decades. In many countries, including the Netherlands, ECEC systems are nowadays complex hybrid markets with a mix of for-profit and not-forprofit organizations providing care and education to young children. The question arises whether system hybridity is compatible with the values of equity and inclusion (Ball 2009; Kaga et al. 2010; Knijn and Lewis 2017; Lloyd 2020; Penn 2011; Vandenbroeck 2017).

In this study we take the Dutch hybrid, privatized and marketized ECEC system as a case in point. We examine how in the context of this system organizations providing care and education to young children deal with the complications of diversity and respond to the public task of supporting equity and inclusion. In the Netherlands, $24.4 \%$ of the total population has an immigrant background, both Western (10.5\%), being mostly immigrants from member states of the European Union, and Non-Western (13.9\%), being mostly immigrants from former Dutch colonies in the Caribbean and from labor migration countries such as Morocco and Turkey (Statistics Netherlands 2020a; b). Adopting an organizational-sociological approach, we evaluate to what extent ECEC organizations succeed in providing a culturally inclusive climate of high quality that may support diverse children's sense of belonging, development, and educational opportunities.

\section{Privatization and marketization of ECEC}

Privatization (withdrawal of the state from the supply-side) and marketization (the shift from supply-driven to demand-driven provision in a competitive market) have been introduced in the public domain of ECEC in many countries in the past decades, challenging ECEC organizations to reconcile divergent public and private objectives in a single organizational configuration (Ball 2009; Denis et al. 2015; Skelcher and Smith 2015). State withdrawal implies larger responsibilities of private parties for general public tasks but, in combination with increased freedom of choice, also leads to differentiation between organizations providing particular services (Ball 2009; Brandsen et al. 2006; Van der Werf et al. 2020), also in ECEC (Brennan 2016; Naumann 2011). Differences between organizations and patterns of segregation may emerge, for example, regarding the demographic background of the children cared for, the flexibility of use, the work climate, and the quality of education and care provided to children. Studies in Australia (Brennan 2016; Press and Woodrow 2018), Germany (Ernst et al. 2014; Mierendorff et al. 2018), the United Kingdom (Blanden et al. 2016; Lloyd and Penn 2012), and the 
Netherlands (Kok et al. 2020; Noailly and Visser 2009) have shown that privatization and marketization tend to strengthen unequal access to high-quality ECEC, favoring high income groups, and withdrawal of provision from remote, rural or poor areas with low purchasing power.

To counteract the tendencies of differentiation and unequal access to quality, and to ensure minimum quality of ECEC for all children, governments usually rely on statutory quality standards and, in many countries, national curricula or national curriculum guidelines. Even in deeply privatized ECEC systems, such as in Australia and the United Kingdom, extensive standards have been defined to regulate the admission of providers to the market and to monitor their performance (Brennan 2016; Knijn and Lewis 2017; Naumann 2011; Newberrry and Brennan 2013; Penn 2011). Prominent in these frameworks are the requirements regarding structural quality (Howes et al. 2008), referring to the group size, the children-to-staff ratio, the number of square meters per child in the center, basic safety and health measures, the training level of staff, and several related conditions. In addition, these frameworks specify value-based socialization goals and sometimes include detailed curriculum and pedagogy guidelines to regulate the process quality of the care and education provided (Naumann 2011; Penn 2011), referring to the emotional and educational aspects of the day-to-day social interactions in the ECEC center (Howes et al. 2008).

In an analysis of the quality frameworks and national curricula of 12 European countries, including countries with predominantly public ECEC systems (e.g., Denmark, Finland, Norway) and countries with privatized and marketized ECEC systems (e.g., Germany, the Netherlands, the United Kingdom), Sylva et al. (2015) found strong agreement across countries on structural quality characteristics and high consensus about a child-centered play-based pedagogy. In addition, most frameworks were rather detailed regarding basic academic and social-emotional competences as desired child outcomes of ECEC. Frameworks and curricula also included references to multicultural education and care, cultural inclusion and multilingual development, however mostly as open recommendations without specifying measures that should be in place or requirements regarding staff competences (Sylva et al. 2015: p. 45).

A key question is if statutory frameworks and curriculum guidelines can impact practice in the desired way, in particular regarding the quality and inclusiveness of the dayto-day processes of education and care. There are three reasons for doubt. First, setting easy to measure, 'hard' minimum structural quality standards may ensure a lower bound of quality but does not guarantee equally high process quality for all children. Studies indicate that the relationship between these characteristics and the quality of the education and care processes is overall weak and not consistent (Dennis and O'Connor 2013; Howes et al. 2008; Slot 2018a; Slot et al. 2015a, b; Sylva et al. 2004). Instead, 'soft' conditions, usually not addressed in national frameworks, such as the opportunities for continuous professional development for staff and the collegial support experienced at the ECEC center, have been found to be stronger related to process quality (Bloom et al. 2010; Dennis and O'Connor 2013; Slot et al. 2015a, b; Tsigilis et al. 2006). Second, official curriculum guidelines and core goals for development and learning may only be weakly related to the actually implemented curriculum (Sylva et al. 2015). This may hold true especially for open, less easy to monitor aspects such as dealing with diversity 
and promoting inclusion and sense of belonging among children. Third, regulation by statutory frameworks, curricula and curriculum guidelines assumes a mechanistic chain between the framework and desired practice (Nutt 2002), and neglects the mediating and moderating role of the organizations that provide care and education (Clegg and Hardy 1999; Mintzberg et al. 2005; Moore 2014). Particularly in hybrid systems, ECEC organizations face different, sometimes opposing forces and institutional logics, and organizations may differ especially in their solutions to reconcile market concerns and public concerns (Quinn et al. 1988; Skelcher and Smith 2015).

\section{Organizations as mediating links}

Following sociological contingency theory, we presuppose that organizations adapt their strategies and change their structure and internal culture in response to the complex and continuously changing environment (Denis et al. 2015; Mintzberg et al. 2005). A key question for the present topic is how organizations providing ECEC within a privatized and marketized hybrid system, such as in the Netherlands, adapt their organizational strategies in the wider context of increasing diversification. More specifically, we examine whether the divergent demands and incentives in this complex environment are associated with organizational differentiation, and how this differentiation in turn relates to the inclusiveness and quality of the care and education provided to children.

To examine these questions and to identify different types of organizations, focusing on the Netherlands, we used Mintzberg's typology of six basic organizational configurations (Mintzberg 1983; Mintzberg et al. 2005; Quinn et al. 1988). The simple structure organization, according to this typology, is characterized by direct, centralized staff supervision by one boss, often the owner. This type of organization has a small-scale organic structure, limited resources for overhead tasks such as professional development, and responds to the demand for flexible client-centered services in a local market. Although making profit is a goal, there is not a strong pull for commercial expansion. The professional bureaucracy emphasizes the continuous training of skilled autonomous professionals to maintain high-quality standards. This type of organization is characterized by a hierarchical administrative structure, line-management, standardization of procedures throughout the organization, and responds to a stable, non-competitive environment that demands complex services of high quality. The commercial division organization in Mintzberg's typology is a large organization characterized by a strong market-orientation. This type of organization responds to the pull to provide flexible, client-centered complex services in a competitive (regional, national or even global) market by splitting into semi-independent divisions with strong middle management, while the pull to increase profits and dividends for shareholders dominates decision-making. The adhocracy, according to Mintzberg, reflects organizations with little formalization and high mutual adjustment that deal with complex or innovative issues but usually on a temporary project basis, while the machine bureaucracy refers to strongly hierarchical, technocratic organizations with low autonomy for employees and a high degree of job specialization for highly standardized (often simple) products, either for public or commercial purposes. Finally, the missionary organization responds to a pull to contribute to societal change. This type of organization is built around a core value-based mission, 
which is shared among the team of staff. There is little hierarchy and standardization, and there is no commercial goal.

The basic presupposition of the present study is that the adaptation of ECEC organizations to the complex environment in which they work mediates and moderates the impact of statutory quality regulations and curriculum guidelines on the provided education and care, in particular how the values of inclusion and equity are reflected in an organization's performance. The present study contributes to the field in two ways. Numerous studies have addressed the relationship between structural and process quality (for overviews, see Slot et al. 2015a; Slot 2018a) and a number of studies have examined the relationships between single aspects at the organization level and process quality, such as leadership, team cohesion and work climate (Bloom et al. 2010; Dennis and O'Connor 2013; Lower and Cassidy 2007; Sylva et al. 2004). However, to the best of our knowledge, there has been no research examining how configurations of organizational characteristics, constituting organization types, are associated with process quality. In addition, our focus on the level of organizations allows us to address how the effect of national standards and curriculum guidelines on quality is mediated and moderated by ECEC organizations.

\section{The Dutch ECEC system}

The Dutch ECEC system was traditionally split into different types of care and education for different age groups in the age range from 0 to 4 years, with different funding systems, different public tasks, and subjected to different government bodies (for overviews, see Akgündüz and Plantenga 2014; Knijn and Lewis 2017; Slot 2018b). At age four, children in the Netherlands are eligible for full-day kindergarten, which is part of the publicly funded primary school system and free of charge. The system for under fours was formally privatized and marketized in 2005 (Dutch Government 2005). In 2010, new legislation was introduced to harmonize the ECEC sector (Dutch Government 2010). A single statutory quality framework was introduced for all types of ECEC regardless of legal entity of the organization and type of funding. The harmonized quality framework specifies age-dependent equal structural quality and health and safety conditions, and defines equal developmental goals and global curriculum guidelines for all ECEC services. Furthermore, within this harmonized system, all services are equally eligible for additional subsidy within the national educational equity policy to reach out to disadvantaged children and to provide them with high-quality early education and care.

The national quality framework, while referring to children's rights and implying equality of opportunities, lacks explicit requirements regarding cultural diversity and inclusion. The framework, however, does state that Dutch is the only language to be used in ECEC, with the exception of Frisian, the officially recognized heritage language of the province of Friesland in the Netherlands (Dutch Government/Childcare Act 2020). This statement reflects the shift in the public and political discourse in the Netherlands in the past decades from embracing multiculturalism to an emphasis on assimilation (Bonjour and Scholten 2014; Penninx 2008).

In a previous study (Van der Werf et al. 2020), the Mintzberg framework was applied to data of a national study on the quality of daycare and preschool provision collected in 2012 to address how ECEC organizations adapt to the hybridity of 
the Dutch ECEC system. In a sample of 127 ECEC organizations information was obtained from managers on organizational characteristics. Using cluster analysis, four types of organizational configuration were identified, matching the Mintzberg idealtypes: the professional bureaucracy, the simple structure firm, the market-driven division organization, and the missionary organization, while also revealing organizational hybridity. The most hybrid type of organization showed a mix of characteristics of the professional-bureaucratic, service-oriented commercial and socially engaged missionary organization. This type was found to provide the highest quality, both in terms of the inclusive work climate experienced by staff, the implemented curriculum reported by staff, and the independently observed quality of care and education provided to children, using the Classroom Assessment Scoring System (CLASS Toddler version; La Paro et al. 2011), an internationally widely used observation instrument to assess the emotional and educational process quality of the provided care and education. Considering the similarities and differences between the four types, we concluded that the missionary social engagement of ECEC organizations was the most distinguishing characteristic, reflected in team cohesion, outreach activities to disadvantaged families and endorsement of an educational-emancipatory mission.

\section{Current study}

The current study aimed to replicate the previous findings regarding organizational configurations using recent data from a nationally representative sample of ECEC centers collected in 2017 and 2018. In addition, the current study focused specifically on the topic of diversity and inclusion. Although cultural diversity and inclusion are not explicitly addressed in the Dutch national quality framework for ECEC, the increasing cultural diversification compels ECEC organizations to respond and take a stance. This pertains to debated issues such as the use of heritage languages, the adaptation of everyday care practice to specific cultural and religious preferences, if and how in the daily program of activities cultural differences and other manifestations of diversity are addressed, and to what extent organizations support children with special and additional needs, including children who have to learn the majority language and basic pre-academic skills for a fair start in formal education. Based on the previous findings, dating from 2012 and briefly discussed above, we expected to find different types of organizations in the Dutch ECEC system in 2017-2018, with types also showing organizational hybridity to some degree (Van der Werf et al. 2020). We furthermore expected that these types of organizations would differ in the extent to which they would serve children with diverse backgrounds and provide them with both a culturally inclusive climate as well as high educational quality. We addressed the following research questions: (1) Are there, as in the previous study, different types of organizations in the Dutch hybrid ECEC system that represent distinct adaptations to the wider social and policy context? (2) If so, do the identified types of organization differ in performance with regard to (a) the proportion of children with special and additional needs or from low socioeconomic status families and nonDutch minorities served by the organization, and (b) the inclusiveness and quality of education and care provided to the children? 


\section{Method}

\section{Participants}

The present study used data collected in 2017 and 2018 within the Dutch national daycare quality monitor study, commissioned by the Ministry of Social Affairs and Employment (Slot et al. 2018b). The study was approved by the Ethical Review Board of the Faculty of Social and Behavioural Sciences of Utrecht University (reference 19-270). Approval included the data management plan and privacy protection measures, designed in compliance with the European Union's General Data Protection Regulations. The monitor started in 2017 and applies a rolling sampling method. Every year, a sample of different forms of early care and education provision is drawn following a stratified sampling model according to region of the country, degree of urbanization, and size of the center, to create a large, nationally representative sample over consecutive years. The annual samples include center-based full day care for 0- to 4-year-olds, half-day education programs for 21/2- to 4-year-olds, after-school care for 4- to 12 -yearolds, and nonfamilial home-based care for 0- to 12-year-olds. For the present purpose we focused on half- and full-day education and care programs for under fours, currently used by about $70 \%$ of Dutch children in this age-range. In 2017, 64 centers were sampled (positive response rate 47.4\%) and in 2018 a new set of 64 centers were added (positive response rate $36.6 \%$ ), roughly equally divided over half- and full-day programs. Reasons for non-response did not reveal systematic biases and mostly concerned lack of time and the response rates were similar to the response rates of previous Dutch ECEC studies (Slot et al. 2018a; b, c). In each center, one group with one or two teachers per group was randomly selected for the study. For each group, in addition to classroom observations by research assistants, the teachers were invited for a personal interview using a structured questionnaire, while the managers of the centers were asked to fill out an online structured questionnaire. The questionnaires were developed based on previous studies into structural, process and curriculum quality, and approaches to staff professionalization in ECEC (2020; Howes et al. 2008; Jenkins and Duncan 2017; Sylva et al. 2015; Van der Werf et al. 2020; Zaslow et al. 2010). In 2017 and 2018 combined, information was obtained from teachers for 119 (93.0\%) and from managers for 117 (91.4\%) of the 128 participating centers. The final sample size was 117 . Note, however, that there were occasionally missing data, which will be discussed below.

\section{Measures and procedures}

\section{Organizational characteristics (managers)}

Managers filled out an online questionnaire addressing the center's organizational structure, culture and policies as derived from the Mintzberg framework outlined above. Based on the managers' responses, the following organizational characteristics were defined (descriptive statistics are presented in Table 1):

Legal entity was indicated by the managers on a four-point scale, representing the main types of legal entity in Dutch ECEC. For the planned cluster analysis (see below, "Analysis" section), to obtain a more equal score distribution, the scale was recoded into the values 0 (for-profit single-owner firms, for-profit companies with shareholders and/ or private equity) and 1 (non-profit foundations). 
Table 1 Descriptive statistics of the organizational characteristics (managers' reports; $N=117)$

\begin{tabular}{|c|c|c|c|c|}
\hline Categorical variables & Value & Label & $f$ & $\%$ \\
\hline \multirow[t]{5}{*}{ Legal entity } & 1 & Foundation & 67 & 59.8 \\
\hline & 2 & Foundation under holding & 9 & 8.0 \\
\hline & 3 & Firm, single owner & 15 & 13.4 \\
\hline & 4 & Company & 21 & 18.8 \\
\hline & Missing & & 5 & \\
\hline \multirow[t]{3}{*}{ Profit goal } & 0 & No profit goal & 81 & 75 \\
\hline & 1 & Profit goal & 27 & 25 \\
\hline & Missing & & 9 & \\
\hline \multirow[t]{7}{*}{ Presence of the manager } & 1 & $<1$ day present & 38 & 32.5 \\
\hline & 2 & 1 day present & 11 & 9.4 \\
\hline & 3 & 2 days present & 12 & 10.3 \\
\hline & 4 & 3 days present & 19 & 16.2 \\
\hline & 5 & 4 days present & 25 & 21.4 \\
\hline & 6 & 5 days present & 12 & 10.3 \\
\hline & Missing & & 0 & \\
\hline Continuous variables & Observed range & Mean & SD & Missing \\
\hline Number of services & $1-5$ & 2.00 & 1.04 & 4 \\
\hline Autonomy of the manager & $2.00-5.00$ & 3.15 & 0.74 & 16 \\
\hline Size center (employees) & $1-60$ & 9.14 & 8.27 & 16 \\
\hline Percentage tenured staff & $0-100 \%$ & $75 \%$ & $26 \%$ & 18 \\
\hline Flexibility user-contracts & $1.00-3.00$ & 1.45 & 0.70 & 12 \\
\hline Positive diversity climate & $0.00-4.00$ & 2.26 & 1.29 & 2 \\
\hline Professional development & $1.00-2.73$ & 1.97 & 0.35 & 13 \\
\hline Team-professionalization & $1.25-5.38$ & 3.10 & 0.96 & 13 \\
\hline Service profile & $1.00-5.00$ & 3.07 & 1.33 & 13 \\
\hline Inclusive profile & $1.00-5.00$ & 3.60 & 0.82 & 13 \\
\hline Contact parents_-group & $0.00-1.00$ & 0.48 & 0.35 & 13 \\
\hline Contact parents_-outreach & $0.00-1.00$ & 0.34 & 0.24 & 13 \\
\hline Contact local schools & $1.00-6.00$ & 3.09 & 1.24 & 13 \\
\hline Contact local services & $0.00-1.00$ & 0.54 & 0.29 & 15 \\
\hline
\end{tabular}

Profit goal represented whether, according to the managers, positive results of the business operations, if any, remained within the center or wider organization of which the center was part (e.g., spent on additional professional development) or were also partly distributed as dividends to shareholders and/or private equity investors, dummycoded into 0 ('no profit to shareholders; positive business results remain in the company') or 1 ('profit is distributed to shareholders').

Number of services referred to the different types of childcare services provided by the center and center's wider organization, concerning in particular full-day care, half-day care, a targeted education program, integrated full-day care and kindergarten, and afterschool care for older children. If one or two services were provided, the number of services was recoded as 0 , if more than two services were provided the number of services was recoded as 1 .

Presence of the manager at the center was based on a single item, asking managers to indicate how many days per week they, as managers, were present at the local center. The 
values ranged from 1 ('less than 1 day per week') to 6 ('all days of the week'). Low presence was regarded as indicating hierarchical line-management with a specific focus on staff supervision, high presence as indicating decentralized all-round management, associated with performing general managerial tasks, including administration, staff supervision, finance and planning (Mintzberg 1983; Mintzberg et al. 2005; Quinn et al. 1988; Van der Werf et al. 2019). For the subsequent analyses, to obtain a more equal distribution of scores, the scale was recoded into two levels, with values 0 ('maximum 2 days present') and 1 ('3 to 5 days present').

Managers' perceived autonomy was based on seven five-point scales (Cronbach's alpha $=0.693$ ) asking the managers to rate the degree of perceived autonomy in their daily work regarding administration, educational decision-making, human resource management, and budgeting. Based on median split, the scale was recoded into 0 (values 1 to 2.99 ) and 1 (values 3.00 to 5 ; 'high perceived autonomy').

Size of the center was based on managers' answers on the question how many licensed teachers (by head count), excluding support staff and interns, were employed at the center. Based on median split, the scale was recoded into the values 0 ( 1 to 10 ; 'small') and 1 (11 or more employees; 'large').

Percentage of staff with tenure (fixed, non-flexible contracts) is the reported number of licensed teaching staff with a fixed tenure divided by all licensed staff at the childcare center, ranging from 0 to $100 \%$ in the current sample. For the purposes of the present analysis, based on median split, the variable was recoded into 0 ('less than $80 \%$ of staff are tenured') and 1 (' $80 \%$ or more of the staff are tenured').

Flexibility of users' contracts was based on three items, asking managers to indicate on a three-point scale to what extent parents were allowed to bring or pick-up their children at flexible times and to change days (1 'not flexible', 2 'somewhat flexible', 3 'flexible'; Cronbach's alpha $=0.868$ ). The mean scores were recoded into 0 (original value 1 ; 'not flexible') and 1 (original values 1.01 to 3 ; 'flexible').

Positive diversity and inclusiveness climate was based on four dichotomous items, addressing: how important it is to the center, according to the manager, to provide equal opportunities to all children (with answers ranging from 1 'not important at all' to 5 'very important', which, because of a skewed score distribution, were recoded into 0 'not important at all to important' and 1 'very important'); whether children are allowed to use their heritage languages at the center ( 0 'no', 1 'yes'); if centers provide information in several languages and try to communicate with parents in their heritage languages $(0$ 'no', 1 'yes, as much as possible'); and if the center would adapt to particular religious or cultural preferences for food and dressing ( 0 'no', 1 'yes, as much as possible'; Cronbach's alpha $=0.381$ ). Although Cronbach's alpha was below standards, we decided to keep the variable as a meaningful count of the number of implemented measures of positive adaptation to cultural diversity, ranging from 0 to 4 . For the subsequent analyses, the final scale was dichotomized into 0 (scores from 0 to 2 ) and 1 (scores 3 and 4, indicating an overall positive diversity and inclusiveness climate).

Supply of different forms of professional development was an eleven items variable, asking managers to rate whether educational staff were regularly provided with different types of personal professionalization activities with values 1 (hardly ever), 2 (yes, but incidentally) and 3 (yes, systematically) (Cronbach's alpha $=0.678)$. Examples 
of activities are attending work-related courses, receiving feedback based on video observation, and receiving personal coaching. For analysis purposes, based on median split, the scale was recoded into 0 (values 1 to 1.99 ; 'hardly ever to incidentally at most') and 1 (values 2 to 3 ; 'systematically').

Team-professionalization was based on eight items, asking managers to indicate the frequency of professionalization activities involving the whole (or most of the) team of educational staff, with values 1 ('never') to 7 ('every day') (Cronbach's alpha $=0.746$ ). The scale was recoded based on median split into 0 (values 1 to 3; 'never to once a month') and 1 (values 3.01 to 7; 'more than once a month').

The organization's mission profile was determined based on each manager's responses to a series of questions in which they had to compare the external mission profile of their organization with other ECEC organizations, rating their answers on a six-point scale with values 1 'not characteristic for my center at all compared to other centers' to 6 'very characteristic for my center compared to other centers'). On conceptual grounds, two mission profiles were distinguished and used in the subsequent analyses.

The service profile comprised four six-point scales (Cronbach's alpha $=0.819$ ). A high score indicated that, according to the managers, providing affordable and flexible care and meeting parents' needs in terms of flexible opening hours was regarded by the manager as particularly characteristic for the center. The scale was recoded based on median split into 0 (values up to 3.34; 'low to moderate service profile') and 1 (3.35 to 6; 'high service profile').

The inclusive profile was based on three six-point scales (Cronbach's alpha $=0.749$ ). A high score indicated that, according to the manager, the center, compared to others, emphasized the importance of giving children in disadvantaged situations a good start, paid positive attention to cultural diversity and strived for inclusion of children with special or additional needs. The scale was recoded based on median split into 0 (scores 1 to 3.68; 'low to moderate inclusive profile') and 1 (scores 3.69 to 6; 'high inclusive profile').

Contact with parents group-wise indicated whether centers did (scored 1) or did not (scored 0 ) organize one or more of the following three types of group-wise activities for parents, based on the managers' reports: thematic conferences (e.g., on topics of child rearing), regular meetings to discuss the center's policy, and festivities such as exhibitions, shows, sports tournaments or barbecues (the final score is the average of three dichotomous items; Cronbach's alpha $=0.464$ ). For the current purpose, the scale was recoded based on median split into 0 (values 0 to 0.50 relatively low on providing group-wise activities for parents') and 1 (values 0.51 to 1.0; 'relatively high on providing group-wise activities for parents').

Contact with parents through outreach activities indicated to what extent, according to the managers, the center actively reached out to parents by implementing one or more of the following type of activities: conducting home visits, involving interpreters and/ or volunteering mediators to establish contact; and providing support information and materials for educational activities at home (average of three dichotomous items; Cronbach's alpha $=0.361$ ). For the current purpose, the scale was recoded based on median split into 0 (values 0 to 0.50 'relatively low on outreach activities towards parents') and 1 (values 0.51 to 1.0 ; 'relatively high on outreach activities towards parents'). 
Finally, the center's local relations were assessed with two indicators. Contact with the local primary school(s) was based on eight five-point scales (Cronbach's alpha $=0.892$ ), asking managers, for example, to indicate the degree of information sharing, educational planning and joint coordination of activities with the nearby primary schools (in particular with the kindergarten departments of these schools, serving children from 4to 6-years of age). For the present purpose, to obtain a more equal distribution of the scores, based on median split, the scale was recoded into 0 (values up to 2.89; 'little to moderate contact') and 1 ( 2.90 to 5 ; 'much contact with schools').

Contact with neighborhood services indicated, according to the managers, whether centers did (scored 1) or did not (scored 0 ) have structural contact with one or more of five types of local organizations and services: primary schools, youth health care centers, family support and social work teams, municipal departments of welfare and education, and neighborhood welfare organizations (average of five dichotomous items; Cronbach's alpha $=0.583$ ). The scale was recoded based on median split into 0 (values up to 0.40 ; 'little to moderate contact') and 1 (0.41 to 1.00; 'much contact with neighborhood services').

\section{Structural classroom characteristics (teachers)}

Teachers were interviewed by research assistants using a structured questionnaire addressing classroom characteristics, their own professional training, and the professional development activities provided to them. For the present purpose, the following structural quality variables were constructed (descriptive statistics are given in Table 3):

Group size was computed as the average number of children in the group during the busiest part (the middle of the morning) of the three busiest days of the week (i.e., Monday, Tuesday, and Thursday), as reported by the teachers.

Children-to-staff ratio was computed by dividing the maximum number of children in the group on regular days by the maximum number of licensed professionals present at the group on these days, thus not including student-teachers on an internship, household personnel, center managers or, occasionally, volunteering parents.

Teacher's education was defined as the highest level of completed formal pre-service education reported by the teachers and was measured on a scale representing the levels of the tracked Dutch secondary and tertiary education system, comprising both vocational and academic programs, ranging from 1 ('lower preparatory vocational education') to 8 ('university education').

Use of an education program reflected the use of a structured, officially accredited program of educational activities, originally developed for working with disadvantaged children but increasingly used for all children. For the present purpose, a dummy variable was created, indicating whether, according to the teachers, an education program was used with the values 0 ('no') and 1 ('yes'), without distinguishing between programs.

The Opportunities for professional development provided to the teachers at the center, as experienced by the teachers, was based on ten five-point scales, ranging from 1 ('never') to 5 ('every day') (Cronbach's alpha $=0.818$ ), addressing, among others, opportunities for attending coursework, receiving personal coaching, and attending conferences for professionals. 
Finally, Type of provision represented whether the classroom offered a full-day program, a half-day program, or combinations of both. For descriptive purposes only, a dummy variable was created with values 0 ('full-day program or a combination of fulland half-day programs') and 1 ('half-day program').

\section{Group composition, children served (teachers)}

Several group composition indicators were computed based on the number of children in the group with a particular family background or special educational needs profile, as indicated by the teacher, divided by the group size. Because of missing values (up to 35\%) in teachers' reports on children's socioeconomic and migrant background, and children's language-support needs, multiple imputation (within SPSS 24) was applied for these variables. Descriptive statistics are presented in Table 4. Low socioeconomic status (SES) background is the teacher-reported proportion of children in the group from families with a low socioeconomic status according to the official criterion in Dutch education policy that both parents were not higher educated than at the preparatory vocational training level. Non-Dutch background, partly overlapping with low-SES background, is the teacher-reported proportion of children whose fathers and/or mothers were born in another country than the Netherlands. Language support needs represents the proportion of children who, according to the teachers, needed extra support in learning the Dutch language, partly overlapping with the indicators low-SES and non-Dutch migration background. Physical and intellectual impairment stands for the reported proportion of children with intellectual impairments: Down syndrome, physical handicaps, and/or chronical illness. Behavior problems indicate the proportion of children in the group with severe problems in the behavioral domain, as experienced by the teacher. Finally, Refugee background refers to the proportion of children from refugee families (mainly from Afghanistan and Syria) and asylum seekers, as reported by the teachers.

\section{Care and inclusion in practice (teachers)}

The inclusiveness of daily practice in the centers was assessed in several ways, based on teacher reports. The following variables were constructed (descriptive statistics are presented in Table 5).

Care for special needs was based on six three-point scales (Cronbach's alpha $=0.732$ ), asking the teacher to rate to what extent measures were taken to accommodate children with special or additional needs and physical handicaps, such as adapting the play room, working with a special needs teacher, and asking support from external experts, with values 1 ('not'), 2 ('more or less') and 3 ('yes'). When teachers answered that particular measures were not applicable, no value was scored if, indeed, no children with special needs were present in the group; otherwise, 1 ('not') if such children were present.

Positive cultural diversity and inclusiveness practice was measured in the same way as with the managers, but now pertaining to the teacher and the group of children with whom the teacher was working on a daily basis. Four dichotomous items addressed how important it is in the view of the teacher to provide equal opportunities to all children (recoded into 0 'not important to important', 1 'very important'), whether the teacher allows children to use their heritage languages in the group ( 0 'no', 1 'yes'), if the teacher tries to communicate with non-Dutch parents in their own languages ( 0 'no', 1 'yes, as 
much as possible'), and if practices are adapted to particular religious or cultural preferences ( 0 'no', 1 'yes, as much as possible'). Cronbach's alpha of the scale was low, 0.418 , yet we decided to keep the variable as a meaningful count of measures at the teacher and classroom level of positive adaptation to cultural diversity.

Stimulating inclusive group activities indicated teachers' beliefs on the importance of inclusive group activities and teachers' employment of strategies to manage these activities, and comprised three items with scores ranging from 1 ('never') to 7 ('always') (Cronbach's alpha $=0.750$ ). An example item is: 'I offer activities for the group as a whole and make sure that all children can participate'.

Intercultural activities and celebrations was a scale based on three items (Cronbach's alpha $=0.513$ ) asking teachers to rate on a seven-point scale how often they would involve children in activities to explore cultural and religious differences, stimulate collaborative play between children of mixed backgrounds, and celebrate important feasts and holy days of other cultural communities, with values ranging from 1 ('never') to 7 ('more than once a day').

The scale Language and literacy learning support comprised seven items (Cronbach's alpha $=0.719$ ), asking teachers to rate on a seven-point scale how often they would create situations to involve children in activities that support children's language development and emergent literacy skills, with values ranging from 1 ('never') to 7 ('more than once a day'). Examples of items are: 'Children are engaged in picture book reading, telling stories based on the pictures' and 'Children participate in circle time conversations, sharing personal experiences'.

The scale Mathematics learning support included five items (Cronbach's alpha $=0.724$ ), asking the teacher to rate on a similar seven-point scale how often they would create situations to engage children in activities that support their emergent numeracy and mathematical skills. Examples of items are: 'Children practice basic counting, play counting games, and name quantities (e.g., I have five marbles)' and 'Children are engaged in measuring activities using a ruler, weighing scales, or measuring cup'.

\section{Process quality in practice (observers)}

The Classroom Assessment Scoring System Toddler (CLASS Toddler; La Paro et al. 2011) was used to assess the classroom process quality. Observers were trained by licensed CLASS trainers and had to achieve at least $80 \%$ agreement within one scalepoint deviation from the trainers in an online test before they were admitted to the study (average agreement was $89.5 \%$; agreement by chance was $33.3 \%$; Slot et al. 2018a, b, c). After passing the online test, the trainers conducted a live observation together with each observer prior to the data collection. Inter-observer agreement of the live observations within one scale-point deviation was 93.5\% (Slot et al. 2018a; b, c). Each classroom was observed on one morning and all classrooms were observed within a 3-month period in the Spring of 2017 and 2018, respectively. Classroom processes and teachers' behaviors were observed during five 15 to 20 min cycles on the observation morning pertaining to situations of free play, structured (educational) activities, creative activities, and mealtime. Quality was rated across eight dimensions, covering two broader domains, and using a seven-point scale with values in three broad ranges: 1 or 2 (classroom is low on that aspect); 3, 4 or 5 (classroom is in the midrange); and 6 or 7 
(classroom is high on that aspect). For the present purpose, domain scores for emotional support and educational support were calculated per classroom and averaged over situations. Emotional support is the average of the scores on five dimensions such as positive climate, reflecting the warmth, respect, and enjoyment displayed during interactions of the teachers and children; teacher sensitivity, indicating the extent to which the teachers are aware of and responsive to individual children's needs; and regard for child perspectives, representing the degree in which teachers' interactions with children match children's interests and support children's autonomy. Educational support is the average of the scores on three dimensions such as facilitation of learning and development, considering how well the teachers facilitate activities that support children's learning and development, and language modeling, referring to teachers' stimulation and modeling of children's use of language. Descriptive statistics of the domain scores are displayed in Table 5.

\section{Analysis}

The analyses proceeded in two steps. First, a k-means cluster analysis in Statistical Package for the Social Sciences (SPSS version 24) was performed on the characteristics of the ECEC organizations as reported by the center managers. A related technique, Latent Class Analysis, was considered not feasible because of the required sample size (Gudicha et al. 2016). K-means cluster analysis is a descriptive non-statistical technique that groups cases on the basis of distances in a Euclidian space without the assumption of existing classes in the population and, therefore, applicable to small samples. A disadvantage of $\mathrm{k}$-means cluster analysis is that statistical criteria to evaluate the cluster solution are lacking. K-means cluster analysis requires variables that are measured on different scales to be standardized or dichotomized. We chose for dichotomization as several variables were either already dichotomous or measured on polytomous ordinal or nominal scales. Weighing different criteria, a three-cluster solution was found most satisfactory, to be detailed further in the "Results" section. Cluster membership was determined for all 117 centers, then merged with the teacher and observation data.

Second, three multivariate analyses of variance (MANOVAs) were conducted, each followed by univariate tests and pairwise comparisons, with cluster membership as the independent variable and, respectively, (1) the set of teacher-reported structural characteristics and indicators of professional development, (2) the indicators of group composition, and (3) the indicators of care and inclusion in practice, together with the observer-rated process quality, as the dependent variables. MANOVAs per set of characteristics were conducted as a first step to reduce the risk of chance findings with multiple testing. If the MANOVAs indicated a significant multivariate effect, we proceeded with univariate tests and pairwise comparisons. The univariate tests and pairwise comparisons further revealed which dependent variables and which contrasts between the organization types contributed most to the multivariate effect.

Although the data had a partially nested structure (teachers within groups; note that groups and centers were coinciding), multilevel analysis was not deemed feasible. Per group, data of only one or a few teachers were available (on average 1.45 per group), not meeting the within-group cluster size for multilevel analysis (Hox 2010). Teacher data were aggregated per group. 


\section{Results}

\section{Organization characteristics}

Frequencies, means and standard deviations of the organization characteristics based on the managers' reports are presented in Table 1. The proportional scores after dichotomization are presented in Table 2, where the rightmost column represents the whole sample of centers.

Most centers in the current sample were foundations (58.9\%), sometimes foundations under a commercial holding (8.0\%). A minority reported distributing profits to external shareholders (25\%). Centers offered on average two different services, but some offered only one and others up to five. Presence of the manager at the centers indicated centralized line-management in about half of the centers (52.2\%) and decentralized all-round

Table 2 Organizational configurations of ECEC centers: mean proportions of centers within clusters meeting the included organizational characteristics $(N=117)$

\begin{tabular}{|c|c|c|c|c|}
\hline Configurations & $\begin{array}{l}\text { Traditional not-for- } \\
\text { profit professional- } \\
\text { bureaucratic } \\
\text { organizations } \\
(N=38)\end{array}$ & $\begin{array}{l}\text { Large } \\
\text { multifunctional } \\
\text { for-profit division } \\
\text { organizations } \\
(N=44)\end{array}$ & $\begin{array}{l}\text { Engaged mixed } \\
\text { for-profit/not-for- } \\
\text { profit professional } \\
\text { organizations } \\
(N=35)\end{array}$ & $\begin{array}{l}\text { All } \\
\text { organizations } \\
(N=117)\end{array}$ \\
\hline $\begin{array}{l}\text { Legal entity (1 = not- } \\
\text { for-profit) }\end{array}$ & 0.97 & 0.32 & 0.79 & 0.67 \\
\hline Profit goal (1 = yes) & 0.00 & 0.64 & 0.18 & 0.29 \\
\hline $\begin{array}{l}\text { Number of services } \\
\text { offered ( } 1=\text { high) }\end{array}$ & 0.32 & 0.71 & 0.73 & 0.59 \\
\hline $\begin{array}{l}\text { Presence of the man- } \\
\text { ager }(1=\text { high })\end{array}$ & 0.37 & 0.77 & 0.23 & 0.48 \\
\hline $\begin{array}{l}\text { Autonomy of the } \\
\text { manager ( } 1=\text { high })\end{array}$ & 0.69 & 0.63 & 0.36 & 0.57 \\
\hline $\begin{array}{l}\text { Size of the center } \\
(1=\text { middle to large })\end{array}$ & 0.16 & 0.63 & 0.09 & 0.32 \\
\hline $\begin{array}{l}\text { Staff on tenure } \\
(1=\text { high })\end{array}$ & 0.61 & 0.30 & 0.65 & 0.51 \\
\hline $\begin{array}{l}\text { Flexibility of users' } \\
\text { contracts ( } 1=\text { high })\end{array}$ & 0.20 & 0.59 & 0.21 & 0.35 \\
\hline $\begin{array}{l}\text { Positive diversity } \\
\text { climate }(1=\text { high })\end{array}$ & 0.16 & 0.26 & 0.65 & 0.36 \\
\hline $\begin{array}{l}\text { Systematic profession- } \\
\text { alization }(1=\text { high })\end{array}$ & 0.43 & 0.53 & 0.83 & 0.59 \\
\hline $\begin{array}{l}\text { Team-based } \\
\text { professionalization } \\
(1=\text { high })\end{array}$ & 0.14 & 0.60 & 0.69 & 0.48 \\
\hline $\begin{array}{l}\text { Service profile } \\
(1=\text { high })\end{array}$ & 0.26 & 0.75 & 0.41 & 0.49 \\
\hline $\begin{array}{l}\text { Inclusive profile } \\
(1=\text { high })\end{array}$ & 0.29 & 0.18 & 0.90 & 0.43 \\
\hline $\begin{array}{l}\text { Contact with par- } \\
\text { ents—-group-wise } \\
\text { (1= high) }\end{array}$ & 0.23 & 0.55 & 0.72 & 0.50 \\
\hline $\begin{array}{l}\text { Contact with } \\
\text { parents_outreach } \\
(1=\text { high })\end{array}$ & 0.14 & 0.08 & 0.59 & 0.25 \\
\hline $\begin{array}{l}\text { Contact with schools } \\
(1=\text { high })\end{array}$ & 0.46 & 0.25 & 0.79 & 0.48 \\
\hline $\begin{array}{l}\text { Contact with local } \\
\text { services }(1=\text { high })\end{array}$ & 0.43 & 0.34 & 0.90 & 0.54 \\
\hline
\end{tabular}


Table 3 Teacher-reported structural characteristics by organizational configuration

\begin{tabular}{|c|c|c|c|c|c|c|c|c|}
\hline & \multicolumn{2}{|c|}{$\begin{array}{l}\text { Traditional } \\
\text { non-profit } \\
\text { professional- } \\
\text { bureaucratic } \\
\text { organizations (C1) }\end{array}$} & \multicolumn{2}{|c|}{$\begin{array}{l}\text { Large } \\
\text { multifunctional } \\
\text { for-profit division } \\
\text { organizations (C2) }\end{array}$} & \multicolumn{2}{|c|}{$\begin{array}{l}\text { Engaged mixed } \\
\text { for/not-for-profit } \\
\text { professional } \\
\text { organizations (C3) }\end{array}$} & \multicolumn{2}{|l|}{ All centers } \\
\hline & $M(\mathrm{SD})$ & $N$ & $M(\mathrm{SD})$ & $N$ & $M(\mathrm{SD})$ & $N$ & $M(\mathrm{SD})$ & $N$ \\
\hline Group size & $14.19(3.11)$ & 34 & $13.27(2.82)$ & 33 & $14.27(3.62)$ & 30 & $13.90(3.18)$ & 97 \\
\hline Children-to-staff ratio & $6.76(1.38)$ & 34 & $5.66(1.22)$ & 33 & $6.53(1.09)$ & 30 & $6.31(1.32)$ & 97 \\
\hline Teacher education level & $5.33(0.66)$ & 34 & $5.30(0.77)$ & 33 & $5.52(0.75)$ & 30 & $5.38(0.73)$ & 97 \\
\hline Use education program & $68 \%(46 \%)$ & 33 & $66 \%(47 \%)$ & 32 & $86 \%(33 \%)$ & 30 & $73 \%(43 \%)$ & 95 \\
\hline Prof. development & $2.01(0.51)$ & 34 & $2.02(0.51)$ & 32 & $2.38(0.55)$ & 29 & $2.13(0.54)$ & 95 \\
\hline
\end{tabular}

management in the other half. The autonomy the managers experienced varied widely, between limited and high autonomy (observed scores on a five-point composite scale ranged from 2.00 to $5.00, \mathrm{SD}=0.74$ ). The size of the centers, based on the number of employed licensed staff, also varied widely with a range of 1 to 60. Most staff employed at the centers were tenured, on average $75 \%$, however with a wide observed range (between 0 and 100\%). Centers also differed in flexibility regarding user contracts with parents (observed score range on a composite three-point scale: $1.00-3.00, \mathrm{SD}=0.70$ ). Overall, managers indicated a moderate positive diversity climate, but both the range of scores and the large standard deviation point to big differences between centers (observed score range on a four-point composite scale: $0.00-4.00, \mathrm{SD}=1.29$ ).

Opportunities for personal and team-based professionalization activities were, on average, provided to some extent with the mean value of personal professionalization indicating 'sometimes' and the mean value of team-based professionalization indicating meeting as a team 'once a month', but again with moderate to large variation (observed range on a three-point composite scale: $1.00-2.73, \mathrm{SD}=0.35$, respectively, on a sevenpoint composite scale: $1.25-5.38, \mathrm{SD}=0.96)$. Centers, on average, tended to profile themselves as moderately service-oriented and as rather inclusive, but again with substantial variation across centers (observed score ranges on two composite five-point scales: $1.00-5.00, \mathrm{SD}=1.33$, and $1.00-5.00, \mathrm{SD}=0.82$, respectively). Variation was also present in the two indicators of centers' contacts with parents and the two indicators of centers' contacts with other local organizations. Contacts with parents through outreach activities was relatively rare (the mean proportion of outreach activities used, out of three possibilities, was 0.24 ; observed range: $0.00-1.00, \mathrm{SD}=0.24$ ). Finally, almost all variables had missing values, amounting to $15 \%$ in one case. Missingness was due to the length of the questionnaire (more missing values towards the end of the questionnaire) and sometimes also due to the lack of precise knowledge on the part of the informant.

Descriptive statistics of the teacher-reported structural, group composition, care and inclusion in practice characteristics, and the observer-rated process quality are presented in Tables 3, 4 and 5 and will be briefly discussed in relation to the MANOVAs.

\section{Configurations of organizational characteristics}

To identify configurations, or types, of organizations, k-means cluster analysis in SPSS 24 was applied to the binary recoded organization characteristics as reported 
Table 4 Teacher-reported group composition characteristics (partly overlapping) by organizational configuration

\begin{tabular}{|c|c|c|c|c|c|c|c|c|}
\hline & \multicolumn{2}{|c|}{$\begin{array}{l}\text { Trad. non-profit } \\
\text { professional- } \\
\text { bureaucratic } \\
\text { organizations (C1) }\end{array}$} & \multicolumn{2}{|c|}{$\begin{array}{l}\text { Large } \\
\text { multifunctional } \\
\text { for-profit division } \\
\text { organizations (C2) }\end{array}$} & \multicolumn{2}{|c|}{$\begin{array}{l}\text { Engaged mixed } \\
\text { for/not-for-profit } \\
\text { professional } \\
\text { organizations (C3) }\end{array}$} & \multicolumn{2}{|l|}{ All centers } \\
\hline & $M(\mathrm{SD})$ & $N$ & $M(\mathrm{SD})$ & $N$ & $M(\mathrm{SD})$ & $N$ & $M(\mathrm{SD})$ & $N$ \\
\hline Low SES background & $31.2 \%(23.8)$ & 34 & $23.1 \%(22.9)$ & 33 & $42.5 \%(25.7)$ & 30 & $32.0 \%(25.1)$ & 97 \\
\hline Non-Dutch background & $26.3 \%(22.9)$ & 34 & $26.8 \%(24.3)$ & 33 & $32.0 \%(25.7)$ & 30 & $29.9 \%(25.2)$ & 97 \\
\hline Language support needs & $21.3 \%(22.7)$ & 34 & $18.3 \%(17.5)$ & 33 & $40.9 \%(27.9)$ & 30 & $26.3 \%(24.7)$ & 97 \\
\hline Phys./intel. impairments & $2.3 \%(5.1)$ & 32 & $2.6 \%(5.0)$ & 33 & $2.5 \%(4.8)$ & 30 & $2.5 \%(4.9)$ & 95 \\
\hline Behavioral problems & $5.8 \%(8.8)$ & 32 & $5.0 \%(7.5)$ & 32 & $8.0 \%(13.0)$ & 30 & $6.2 \%(10.0)$ & 94 \\
\hline Refugee status & $0.5 \%(1.8)$ & 31 & $1.3 \%(3.9)$ & 33 & $5.4 \%(13.3)$ & 30 & $2.3 \%(8.1)$ & 94 \\
\hline
\end{tabular}

Table 5 Teacher-reported group composition characteristics (partly overlapping) by organizational configuration

\begin{tabular}{|c|c|c|c|c|c|c|c|c|}
\hline & \multicolumn{2}{|c|}{$\begin{array}{l}\text { Traditional } \\
\text { non-profit } \\
\text { professional- } \\
\text { bureaucratic } \\
\text { organizations (C1) }\end{array}$} & \multicolumn{2}{|c|}{$\begin{array}{l}\text { Large } \\
\text { multifunctional } \\
\text { for-profit division } \\
\text { organizations (C2) }\end{array}$} & \multicolumn{2}{|c|}{$\begin{array}{l}\text { Engaged mixed } \\
\text { for/not-for-profit } \\
\text { professional } \\
\text { organizations (C3) }\end{array}$} & \multicolumn{2}{|l|}{ All centers } \\
\hline & $M(\mathrm{SD})$ & $N$ & $M(\mathrm{SD})$ & $N$ & $M(\mathrm{SD})$ & $N$ & $M(\mathrm{SD})$ & $N$ \\
\hline Care for special needs & $2.49(0.36)$ & 26 & $2.39(0.44)$ & 30 & $2.63(0.26)$ & 27 & $2.50(0.37)$ & 83 \\
\hline Cultural inclusiveness & $2.57(1.57)$ & 34 & $2.73(1.33)$ & 33 & $3.92(1.39)$ & 30 & $3.04(1.54)$ & 97 \\
\hline Inclusive group attitudes & $5.27(0.90)$ & 34 & $4.95(1.17)$ & 33 & $5.47(0.98)$ & 30 & $5.21(1.05)$ & 97 \\
\hline Intercultural activities & $2.40(1.15)$ & 31 & $2.73(1.26)$ & 29 & $2.86(1.12)$ & 28 & $2.65(0.96)$ & 88 \\
\hline Language activities & $4.66(1.04)$ & 32 & $5.09(0.74)$ & 29 & $4.90(1.04)$ & 28 & $4.87(1.02)$ & 89 \\
\hline Mathematical activities & $2.85(0.73)$ & 31 & $3.11(0.86)$ & 29 & $3.43(1.00)$ & 28 & $3.12(0.89)$ & 88 \\
\hline Obs. emotional support & $5.60(0.37)$ & 34 & $5.59(0.50)$ & 33 & $5.90(0.39)$ & 30 & $5.69(0.45)$ & 97 \\
\hline Obs. educational support & $3.29(0.54)$ & 34 & $3.00(0.77)$ & 33 & $3.67(0.63)$ & 30 & $3.31(0.70)$ & 97 \\
\hline
\end{tabular}

by managers, with the option of pairwise deletion in case of missing values. Cluster analysis does not provide overall goodness of fit, comparative fit or entropy measures to decide on a particular solution. It is recommended to compare a number of cluster solutions and to weigh parsimony and several other criteria to evaluate these solutions relative to each other. We examined solutions with two, three, four and five clusters. The two-clusters solution did not reproduce theoretically and policy-relevant distinctions regarding the number of services provided, the degree of manager autonomy, the share of tenured staff, the investment in systematic professional development and the provision of group-wise activities for parents (ANOVAs indicated no statistically significant effects of these characteristics on the cluster differentiation). The mean distance of centers to cluster centroids was 1.74 $(\mathrm{SD}=0.34)$.

The three-clusters solution reproduced all relevant distinctions regarding organizations' structure, culture and alliances (all theoretically derived organization characteristics contributed statistical significance to the differentiation in clusters). Centers were reasonably evenly distributed over clusters, with the smallest cluster containing 
35, the middle size cluster containing 38 and the largest 44 centers. The mean distance of centers to cluster centroids was $1.65(\mathrm{SD}=0.35)$, smaller than found for the two-clusters solution.

The four-clusters solution, compared to the three-clusters solution, also reproduced all relevant distinctions, however less clearly interpretable from an organizational-sociological point of view as one cluster could not be clearly distinguished from the other three clusters on most indicators. Moreover, the distribution of centers over the cluster solution was slightly more unbalanced, with one cluster containing only 22 centers whereas the other three clusters contained 31, 32 and 33 centers, respectively. The mean distance of centers to cluster centroids was $1.61(\mathrm{SD}=0.34)$, not much smaller than for the three-clusters solution.

Finally, the five-clusters solution resulted in a further distinction between small-size and large size for-profit organizations, resulting in two relatively small clusters (13 and 14 centers, respectively) compared to the other clusters. The mean distance of centers to cluster centroids was $1.57(\mathrm{SD}=0.34)$, not much smaller than found for the three- and four-clusters solutions. Weighing parsimony, theoretical relevance, evenness of cluster sizes, mean cluster distances, and interpretability, we chose the three-clusters solution for the subsequent analyses.

Table 2 shows the clusters with the cluster structure parameters. Cluster 1 consists of centers that are mainly not-for-profit organizations characterized by low manager presence, which is indicative of hierarchical line-management and centralized administrative support (Van der Werf et al. 2019). A majority of the centers in this cluster are smallsized, have $80 \%$ or more of staff on tenured contracts, do not allow users much flexibility, and do not profile themselves as service-oriented nor as inclusive-emancipatory. In addition, the vast majority of centers in this cluster score low on the count of implemented measures to create an inclusive climate. Altogether, these structural characteristics predominantly match the ideal-type of the traditional professional-bureaucratic organization of the Mintzberg typology. Two aspects do not fit this type of organization, however. In the majority of centers, the managers reported to experience relatively high autonomy, while in contrast, implementation of systematic professionalization was not overly prominent and a team-orientation in professionalization activities was virtually absent, suggesting a change in this type of organization with regard to the prominence of professional performance as a central objective, as will be discussed later. Focusing on the predominant traditional professional-bureaucratic structure, we identified cluster 1 centers $(N=38)$ as traditional not-for-profit professional-bureaucratic organizations.

Cluster 2 represents predominantly for-profit organizations, of which several report to distribute dividends to shareholders. The vast majority of centers have decentralized allround management, with managers experiencing a relatively high degree of autonomy. Cluster 2 centers mostly offer multiple services in relatively large centers, while only a minority have $80 \%$ or more of staff on tenured contracts. The service-orientation is prominent, also in comparison to the other clusters. A majority of centers allow flexibility in the user contracts with parents and a vast majority emphasize providing service to parents as main focus of their external profile, but not inclusion-emancipation. Few centers report a high count of implemented positive diversity and inclusiveness measures. Few centers report to employ activities to reach out to (difficult-to-reach) parents. 
Likewise, only a minority of centers in this cluster report structural collaborative relationships with local schools and neighborhood services. Altogether, the characteristics of the centers in cluster 2 predominantly match Mintzberg's ideal-type of the marketdriven for-profit division organization. Two aspects do not fit this ideal-type: a (small) majority of cluster 2 centers report to systematically provide staff with opportunities for professionalization and to focus on team-based professionalization. This may point to organizational hybridity, as will be discussed below. Focusing on the predominant pattern, we identified cluster 2 centers $(N=44)$ as large, multifunctional, for-profit division organizations.

Cluster 3, like cluster 1, represents centers that are in majority not-for-profit foundations, but a number of centers in this cluster are commercial with a profit goal and the vast majority of centers in this cluster, like centers in cluster 2 , offer multiple services to children and parents. Management in most cluster 3 centers is hierarchical in-line and managers in most centers report relatively little autonomy. Almost all centers are small sized, while the majority of centers have more than $80 \%$ of staff tenured. Most centers do not allow parents high contractual flexibility, although a substantial number of centers, more than in cluster 1, emphasize a service-to-parents orientation in their external profile. The majority of centers implement a policy of systematic staff professionalization and in most centers professionalization has a relatively strong team-orientation. Distinguishing features of cluster 3, compared to the other clusters, are that the (vast) majority of centers in cluster 3 report to implement several, above average positive diversity and inclusiveness measures, emphasize inclusion-emancipation in their external profile, maintain contact with parents through group meetings and outreach activities, while the vast majority of the centers of cluster 3 are also well-connected to local schools and neighborhood services. These characteristics altogether match the main coordination mechanisms of Mintzberg's ideal-type of the professional-bureaucratic organization as well as of the ideal-type of the missionary organization, while also aspects of the market-driven service orientation are present. Cluster 3 centers thus reflect more hybridity than the other types, especially compared to the traditional professional-bureaucratic organizations of cluster 1 , to be discussed later. Considering these findings, we identified cluster 3 centers $(N=35)$ as socially engaged mixed for-profit/not-for-profit professional organizations.

Finally, for descriptive purposes (not in Table 1), all clusters contain centers that provide only half-day programs ( $80 \%$ in cluster $1,27 \%$ in cluster 2 and $63 \%$ in cluster 3 ), while all clusters contain centers that provide full-day programs or a combination of half- and full-day programs.

\section{Structural characteristics by cluster}

A multivariate analysis of variance (MANOVA) was conducted with cluster membership as the independent variable and structural characteristics of the group and the center, as reported by the teachers, as the dependent variables. Means and standard deviations are reported in Table 3 and show an average group size of 13.90 (no large differences between clusters) and an average children-to-staff ratio of 6.31, with a smaller ratio in cluster 2 centers due to fact that part of these centers also cared for infants for whom the national quality framework prescribes smaller ratios. The multivariate effect of cluster 
on structural characteristics was statistically significant $\left(F_{(10,172)}=3.041, p<0.001\right.$, partial $\eta^{2}=0.150$; Wilk's lambda). Univariate tests and pairwise comparisons revealed significant effects of cluster on the children-to-staff ratio $\left(F_{(2,92)}=7.130, p<0.001\right.$, partial $\left.\eta^{2}=0.137 ; \mathrm{C} 1, \mathrm{C} 3>\mathrm{C} 2\right)$ and the opportunities for professional development $\left(F_{(2,}\right.$ ${ }_{92)}=4.975, p<0.009$, partial $\eta^{2}=0.100 ; \mathrm{C} 3>\mathrm{C} 1, \mathrm{C} 2$ ). There were no significant differences between the clusters with regard to group size, teachers' training level and use of an education program.

\section{Group composition by cluster}

A multivariate analysis of variance (MANOVA) was conducted with cluster membership as the independent variable and group composition characteristics as the dependent variables. Means and standard deviations are reported in Table 4 and show, for example, that in cluster 3 centers on average $42.5 \%$ of the children cared for have a low-SES background compared to $23.1 \%$ in cluster 2 centers. This partly overlaps with findings that on average $40.9 \%$ of the children in cluster 3 centers have additional language-support needs compared to $18.3 \%$ in cluster 2 centers. The multivariate effect of cluster on group composition characteristics was statistically significant $\left(F_{(12,166)}=2.998, p<0.009\right.$, partial $\eta^{2}=0.143$; Wilks' Lambda). Univariate tests and pairwise comparisons revealed strong significant effects of cluster on the percentages of children with a low-SES background $\left(F_{(2,90)}=4.806, p<0.010\right.$, partial $\left.\eta^{2}=0.098 ; \mathrm{C} 3>\mathrm{C} 2\right)$ and language-support needs $\left(F_{(2,90)}=8.832, p<0.000\right.$, partial $\left.\eta^{2}=0.167 ; \mathrm{C} 3>\mathrm{C} 1, \mathrm{C} 2\right)$, and a borderline significant effect at $p<0.100$ for children with a refugee background $\left(F_{(2,90)}=3.038, p<0.053\right.$, partial $\eta^{2}=0.065$; C3 $\left.>C 1, C 2\right)$. The other univariate tests were not significant, however pairwise comparisons showed a borderline significant higher proportion of non-Dutch children in cluster 3 compared to cluster 1 and cluster 2 centers.

\section{Inclusion, education and care in practice}

Descriptive statistics on inclusion, education and care in practice are presented in Table 5 . They show large differences in the reported average positive diversity climate between cluster 3 and cluster 1 centers (mean scores are 3.92 vs. 2.57, pooled SD =1.54). They also show high observed emotional process quality, with a mean score of 5.69 in the whole sample, well beyond the conventional benchmark of 5 ('good'; La Paro et al. 2011), but higher in cluster 3 centers than in the other centers. The observed educational process quality is above the benchmark of 3 ('just sufficient'), as is usually found in studies in several countries using the CLASS (Slot 2018a), but with large differences between the clusters (e.g., cluster 3: 3.67 vs. cluster 2: 3.00 , pooled $\mathrm{SD}=0.45$ ).

A MANOVA was conducted with cluster as independent and the teacher-reported inclusive practices and observer-rated process quality as dependent variables. Because of the relatively large number of missing values, which would severely reduce the statistical power of the multivariate analysis, the variable Care for special needs was not included in the MANOVA but separately tested. The multivariate effect was statistically significant $\left(F_{(14,158)}=2.960, p<0.000\right.$, partial $\eta^{2}=0.208$; Wilks' Lambda). Univariate tests and pairwise comparisons showed medium-strong to strong effects of cluster on cultural inclusiveness in practice $\left(F_{(2,87)}=8.352, p<0.000\right.$, partial $\eta^{2}=0.164 ; \mathrm{C} 3>\mathrm{C} 1$, $\mathrm{C} 2)$, mathematics learning support $\left(F_{(2,87)}=3.364, p<0.039\right.$, partial $\eta^{2}=0.073$; C3 $\left.>\mathrm{C} 1\right)$, 
observed emotional process quality $\left(F_{(2,87)}=3.771, p<0.027\right.$, partial $\eta^{2}=0.082$; C $\left.3>\mathrm{C} 1\right)$ and observed educational process quality $\left(F_{(2,87)}=5.695, p<0.005\right.$, partial $\eta^{2}=0.118$; $\mathrm{C} 3>\mathrm{C} 2 ; \mathrm{C} 1>\mathrm{C} 2)$. The cluster effect on care for special needs was separately tested with a univariate analysis of variance (ANOVA), yielding a statistically significant mediumsized effect $\left(F_{(2,80)}=3.151, p<0.048\right.$, partial $\eta^{2}=0.073$; C3 $>$ C2 $)$.

No statistically significant effects of cluster were found on teachers' inclusive group attitudes and the intercultural activities provided. Note that the standardized differences between the means of the highest and lowest scoring cluster on these variables (as can be inferred from Table 5) are medium-sized, favoring cluster 3. We also did not find a significant effect of cluster on the language and literacy support activities provided to children, but the trend of the means disfavors cluster 1 centers.

\section{Discussion}

The present study examined how organizations providing early childhood education and care in the Netherlands have adapted to the divergent demands and incentives of the Dutch hybrid ECEC system within the wider context of increasing cultural diversification and social inequality. The study, using data collected in 2017 and 2018, was partly set up as a replication of a previous study using data from 2012 (Van der Werf et al. 2020), but addressed more specifically organizations' diversity and inclusiveness policy.

\section{Organizational differentiation}

Regarding the first research question, whether different types of organizations could be identified in the Dutch hybrid ECEC system, cluster analysis of organizational characteristics derived from the framework of Mintzberg (1983) revealed three distinct types, that were named, respectively, traditional not-for-profit professional-bureaucratic organizations, large multifunctional for-profit division organizations, and socially engaged mixed for-profit/not-for-profit professional organizations. These types matched the ideal-typical configurations proposed by Mintzberg rather closely, but also showed organizational hybridity. Particularly the type socially engaged mixed for-profit/not-for-profit professional organizations combined elements of professional bureaucracies (emphasis on hierarchical line-management, standards and systematic professionalization), commercial division organizations (client-centeredness to some extent, offering multiple services to parents) and missionary organizations (commitment to social-emancipatory and inclusiveness goals). Also the type of large multifunctional for-profit division organizations was hybrid to some extent, especially by integrating elements of the professionalbureaucratic organization type (emphasis on team-based professional development), whereas the traditional professional-bureaucratic organizations seemed to have lost some of the typical characteristics of this type of organization (hierarchical line-management, team-orientation). The latter may reflect changes in adaptation strategy of this type of ECEC organizations, which emerged from the former public municipalityrun ECEC system. Particularly the ongoing take-overs of these former public organizations by large commercial companies due to government withdrawal, could be the cause that their original focus on professional quality and public interests has decreased, while remaining a non-profit legal entity (e.g., a foundation) within a commercial holding (Brancheorganisatie Kinderopvang 2015; Kruiter et al. 2019). Remarkable was the 
apparent lack of social engagement and orientation on the values of inclusion and equity of centers of this type, compared to the socially engaged mixed for-profit/notfor-profit professional organizations. Most of the latter type of ECEC organizations also emerged from the former public system but seemed to have strengthened their orientation on public interests. Note that some of the socially engaged organizations $(21 \%)$ were commercial.

The current findings for the years 2017 and 2018 were largely similar to the findings for the year 2012, reported in our previous study (Van der Werf et al. 2020). The three types of ECEC organizations found in the present study matched closely three of the four types found earlier and our characterizations of the matching types are highly similar, although the set of characteristics to identify the organization types and their operational definitions in both studies differed at some points. The fourth type found in the previous study, namely the small-scale simple structure for-profit firms, could not be replicated in the current study. A likely explanation is that this type of organization was infrequent in the current sample due to a decreased market share over the past years as a consequence of scale enlargement in the Dutch ECEC sector and take-overs by large commercial companies (Brancheorganisatie Kinderopvang 2015; Kruiter et al. 2019).

In our previous study we concluded that commercial objectives, together with client-centeredness and flexibility, on the one hand, and missionary social engagement, together with outreach to parents, on the other hand, were the organizational characteristics that distinguished most between organizations. The present results confirm these findings and add a further distinguishing characteristic, namely the embeddedness of ECEC organizations in networks with other local services (based on indicators not available in the data of 2012), reflecting the collaboration within local networks to tackle the complex problems in the local context (Bryson et al. 2014; Provan and Kenis 2008; Quinn et al. 1988). Centers of the socially engaged mixed for-profit/not-for-profit professional type were more strongly connected to local schools and neighborhood child-, family- and social services than centers of the other two types.

\section{Differences in inclusion and quality}

Regarding the second research question, whether the identified types of organizations differed with regard to the inclusiveness and quality provided, we found partial confirmation of our hypotheses. As expected, ECEC centers within the three types did not differ on basic structural quality characteristics, although the children-to-staff ratio was more favorable in the large multifunctional for-profit centers, due to the fact that several of these centers also cared for infants, obliging them to lower the ratio in line with the national quality framework. Although there were differences in the use of an education program, in all types, the majority of centers reported to use such a program and the differences between the types were not significant. An important difference, however, concerned the implementation of a policy of systematic professionalization as experienced by the teachers, which was higher in the socially engaged professional organizations compared to the other types of organizations.

With respect to the inclusiveness and quality of the centers, a major difference was found regarding the social background and profile of needs of the children cared for. Socially engaged professional organizations, overall, served (partly overlapping) far more 
children of low-SES background, more non-Dutch children, far more children with language-support needs, and more children with a refugee background than centers of the other types, with no clear differences in this regard between traditional professionalbureaucratic organizations, on the one hand, and large commercial organizations, on the other hand. Thus, socially engaged professional organizations were, on average, more inclusive in terms of serving diverse and disadvantaged children than the other types of organizations.

Regarding the inclusiveness and quality of care and education practices, most though not all indicators also revealed the expected differences between the types of organizations. Overall, based on teacher reports, socially engaged professional organizations were more attuned to children with special and additional needs, provided a culturally more inclusive climate to children and parents, for instance by allowing the use of heritage languages at the center (officially not allowed in Dutch ECEC), provided more intercultural activities, were more focused on inclusive group activities (a trending pattern, but statistically not significant), and supported children more in early mathematics learning as a way to prepare them for school. For support to language and literacy learning the differences were smaller and not significant. Finally, the observed emotional and educational process quality, based on the CLASS Toddler (La Paro et al. 2011), differed strongly between the types as well, showing significantly higher quality of the care and education processes in centers of the socially engaged professional type than in centers of the other types. In short, although not completely consistent, we found that the socially engaged professional organizations provided more inclusive and high-quality education and care than the other organizations.

\section{Value-based regulation}

The Dutch ECEC system is after successive reforms fully privatized and harmonized and regulated by a single statutory quality framework for all types of organizations providing education and care to children in the age range from 0 - to 4-years. This framework, as in many other countries, is detailed regarding basic safety and health prerequisites, and also regarding structural quality characteristics such as teachers' pre-service training level, group size, children-to-staff ratio, and available space per child. The Dutch national framework is, compared to the frameworks of other European countries (Sylva et al. 2015) and of countries with comparable split privatized ECEC systems (Brennan 2016; Newberrry and Brennan 2013; Penn 2011), relatively open (or, for that matter, rather underspecified) regarding curriculum guidelines and goals for development and learning, mentioning only broad personal competences and stipulating all children's right to develop optimally. The framework, moreover, does not include specific regulations, requirements or recommendations regarding equal opportunities, diversity and inclusiveness, yet reflects an assimilationist orientation in line with the current Dutch national integration policy (Bonjour and Scholten 2014; Penninx 2008).

In addition to this framework, national education policy, following the national and international scientific evidence (Heckman 2011; Leseman et al. 2017; Melhuish et al. 2015; Van Huizen and Plantenga 2018; Yoshikawa et al. 2013), has initiated substantial public investments in ECEC to prevent early education gaps by making extra subsidy available to ECEC centers that work with disadvantaged children. Although the focus 
is strongly on preparing children for formal education in the domains of language, literacy and mathematics, the policy as such represents the values of equal opportunities and inclusion. As we argued in our previous study (Van der Werf et al. 2020), the introduction of value-based regulation in Dutch ECEC through the system of targeted incentives seems to function as an additional quality regulation system that fills gaps left by the harmonized statutory quality framework that focuses predominantly on structural characteristics.

\section{Hybridity: challenges and opportunities}

The public tasks of providing equal opportunities to all children and supporting the integration in society of children from different ethnic, cultural or linguistic communities are of increasing importance in current societies and ECEC can contribute crucially to these tasks, as is recognized in many countries (European Commission 2018; OECD 2015; Vandenbroeck 2017). System hybridity, as a consequence of privatization with maintenance of public tasks, can be an obstacle to serve these public tasks (Ball 2009; Knijn and Lewis 2017), but may also offer opportunities, especially with regard to more fairly redistributing collective wealth to disadvantaged communities (Van Lancker and Van Mechelen 2015). The present study, as did our previous one, shows that not all types of ECEC organizations are equally capable or motivated to fulfill these public tasks. Depending on the configuration of internal professionalization, shared mission among staff and leadership, outreach to disadvantaged groups, and embeddedness in networks with other local services, some organizations are better capable to serve these public tasks than others, and, as such, they are essential for a fair redistribution of society's collective wealth to those who need it most to compensate for socioeconomic and cultural inequality. The present findings, as did the findings of our previous study, also suggest that national quality regulation frameworks may not be the strongest tools of society to assure quality, equality, compensation for disadvantages, and inclusiveness (see also Sylva et al. 2015). This approach to governing the ECEC system fails to recognize the dynamisms at the level of the ECEC organizations (Bryson et al. 2014; Moore 2014; Nutt 2002; Skelcher and Smith 2015).

The present study relates to the timely questions whether ECEC should be a universal public service with strong state involvement, mainly provided by not-for-profit organizations (Cascio 2017; Lloyd 2020; Penn 2011; Ünver et al. 2018) or, as a farther reaching step, whether ECEC should be integrated in the national public education system (Kaga et al. 2010). There are no simple answers. Advocates of a largely public ECEC system with strong state involvement often point to the predominantly public, unitary systems of the Nordic countries in Europe, with high uptake from an early age and allegedly high quality (Ünver et al. 2018; Lloyd 2020; Naumann 2011; Pavolini and Van Lancker 2018; Penn 2011). However, recent studies in Denmark and Norway, involving large representative samples of ECEC centers, do not show an overall advantage in quality nor equal access to high quality, instead revealing in particular low educational process quality (Baustad and Bjørnestad 2020; Bjørnestad and Os 2018; Bleses et al. 2018; Sibley et al. 2015; Slot et al. 2015a; for an overview and extended discussion, see Leseman and Slot 2020). In contrast, the present findings may suggest that introducing rivaling logics in a privatized and marketized ECEC system (commercial aims and client-centeredness, but 
also a child's rights-based developmental perspective and incentives for social equity) can drive the system as a whole depending on a deliberate mix of incentives, via organizational differentiation, to become more adaptive to the divergent needs and demands of children and parents, more outreaching to disadvantaged communities, more inclusive, and better capable of distributing the highest quality to those who need this most.

There is a clear need for future studies in other countries with both similar (privatized and marketized) and different (largely public) ECEC systems to corroborate the current findings, focusing on the level of ECEC organizations. If findings would converge, they may inform new public governance beyond the binary state versus market models of governance (Ball 2009; Bryson et al. 2014; Provan and Kenis 2008).

\section{Limitations}

Several limitations to the present study should be mentioned. First of all, the sample of ECEC centers for 0- to 4-year-olds was small, and due to non-response and missing values the statistical power of the main analyses was decreased. The moderate positive response rates (on average $42.0 \%$ over the years 2017 and 2018) may have caused a bias in the data. Stable, well managed larger organizations may have been overrepresented in the current sample, while small firms and organizations in transition or less well managed were possibly underrepresented. Nonetheless, there was relevant variation in organization characteristics, which were interpretably associated with the indicators of quality and inclusiveness. Note also that the findings of our previous study on the hybrid Dutch ECEC system, based on data from the year 2012 with a positive response rate of 52.6\% (Van der Werf et al. 2020), could be largely replicated in the current study, which increases the confidence in the present results. Second, the operational definition and measurement of core constructs regarding inclusiveness was limited to only rough indicators due to data availability, while our observational measures based on the CLASS Toddler (La Paro et al. 2011) did not specifically address key aspects of intercultural and multilingual pedagogy in the classroom, such as valuing multiple differences, the integration of intercultural contents in play-work activities, the fostering of critical thinking, and the bridging between children's languages and the majority language (Banks 2015; Cummins 2015). Nonetheless, we believe that the current findings are relevant to the issue of equity and cultural inclusiveness in ECEC as they show a clear differentiation in this regard between different types of ECEC centers operating in a hybrid market.

\section{Conclusion}

Despite these limitations, the present study shows that the hybrid ECEC system of the Netherlands with a mix of commercial and public demands and incentives, is associated with organizational differentiation. The study reveals clear differences between organizations in the inclusiveness and quality of education and care provided to young diverse children, in spite of successive harmonization reforms and the presence of a single, uniform statutory quality framework. System hybridity, as described for the Dutch case, presents challenges but also opportunities. Opportunities are exemplified in particular by the former public, municipality-run organizations who have become more entrepreneurial and client-centered, while also effectively reaching out to disadvantaged communities and providing children in these communities with high-quality inclusive education 
and care. Facilitating these organizations in a hybrid system can contribute to a more fair redistribution of society's collective wealth. Challenges relate to both the formerly public not-for-profit professional-bureaucratic and the large multifunctional commercial ECEC organizations who do not seem to provide the desired high quality nor inclusive context.

\section{Abbreviations}

ANOVA: Analysis of variance; CLASS: Classroom Assessment Scoring System; ECEC: Early childhood education and care; MANOVA: Multivariate analysis of variance; SES: Socioeconomic status; SPSS: Statistical Package for the Social Sciences.

\section{Acknowledgements}

Not applicable.

\section{Authors' contributions}

WW: conceptualization, writing — original draft, formal analysis. PS: investigation, resources, writing —review and editing, supervision. PK: conceptualization, writing - review and editing, supervision. PL: conceptualization, methodology, formal analysis, resources, writing — review and editing, supervision. All authors read and approved the final manuscript.

\section{Funding}

The research reported in this article used data of the Dutch national daycare quality monitor, commissioned by of the Ministry of Social Affairs and Employment, but did not receive any specific grant from funding agencies in the public, commercial, or not-for-profit sectors.

\section{Availability of data and materials}

The data that support the findings of this study are available from the Dutch Ministry of Social Affairs and Employment but restrictions apply to the availability of these data, which were used under license for the current study, and so are not publicly available. Data are however available from the authors upon reasonable request and with permission of the Dutch Ministry of Social Affairs and Employment.

\section{Competing interests}

The authors declare that they have no competing interests.

\section{Author details}

${ }^{1}$ Utrecht University, Heidelberglaan 1, 3584 CS Utrecht, The Netherlands. ${ }^{2}$ Tilburg University, Warandelaan 2, 5037 AB Tilburg, The Netherlands.

Received: 19 February 2020 Accepted: 15 December 2020

Published online: 07 January 2021

\section{References}

Akgündüz, Y., \& Plantenga, J. (2014). Childcare in the Netherlands: Lessons in privatization. European Early Childhood Education Research Journal, 22(3), 379-385.

Ball, S. J. (2009). Privatising education, privatising education policy, privatising educational research: Network governance and the 'competition state.' Journal of Education Policy, 24(1), 83-99.

Banks, J. A. (2015). Cultural diversity and education: Foundations, curriculum, and teaching. New York: Routledge.

Baustad, G., \& Bjørnestad, E. (2020). Everyday interactions between staff and children aged 1-5 in Norwegian ECEC. Early Years. https://doi.org/10.1080/09575146.2020.1819207.

Bjørnestad, E., \& Os, E. (2018). Quality in Norwegian childcare for toddlers using ITERS-R. European Early Childhood Education Research Journal, 26(1), 111-127. https://doi.org/10.1080/1350293X.2018.1412051.

Blanden, J., Del Bono, E., McNally, S., \& Rabe, B. (2016). Universal pre-school education: The case of public funding with private provision. The Economic Journal, 126(592), 682-723. https://doi.org/10.1111/ecoj.12374.

Bleses, D., Højen, A., Justice, L. M., Dale, P. S., Dybdal, L., Piasta, S. B., et al. (2018). The effectiveness of a large-scale language and preliteracy intervention: The SPELL randomized-controlled trail in Denmark. Child Development, 89(4), e342e363. https://doi.org/10.1111/cdev.12859.

Bloom, P. J., Hentschel, A., \& Bella, J. (2010). A great place to work: Creating a healthy organizational climate. Lake Forest, Illinois: New Horizons.

Bonjour, S. A., \& Scholten, P. (2014). The Netherlands. In A. Triandafyllidou \& R. Gropas (Eds.), European immigration: A sourcebook (2nd ed., pp. 262-271). Farnham, England: Ashgate.

Borgna, C., \& Contini, D. (2014). Migrant achievement penalties in Western Europe: Do educational systems matter? European Sociological Review, 30(5), 670-683. https://doi.org/10.1093/esr/jcu067.

Brancheorganisatie Kinderopvang. (2015). Brancherapport 2015, sector kinderopvang:Feiten, cijfers en ontwikkelingen [Child care sector report 2015: Facts, figures and trends]. Retrieved from www.ruimte-ok.nl/sites/default/files/bestanden/ actueel/BrancherapportBenchmark2015def.pdf

Brandsen, T., Van de Donk, W., \& Kenis, P. (2006). Meervoudig bestuur: Publieke dienstverlening door hybride organisaties [Multiple governance: Public services by hybrid organizations]. The Hague, The Netherlands: Lemma.

Brennan, D. (2016). The business of care: Australia's experiment with the marketization of childcare. In C. Miller \& L. Orchard (Eds.), Australian public policy progressive ideas in the neoliberal ascendency (pp. 151-167). Bristol, England: Policy Press. 
Bryson, J. M., Crosby, B. C., \& Bloomberg, L. (2014). Public value governance: Moving beyond traditional public administration and the New Public Management. Public Administration Review, 24(4), 445-456. https://doi.org/10.1111/ puar.12238

Cascio, E. U. (2017). Does universal preschool hit the target? Program access and preschool impacts. Working paper 23215. Cambridge: National Bureau of Economic Research.

Celeste, L., Baysu, G., Phalet, K., Meeussen, L., \& Kende, J. (2019). Can school diversity policies reduce belonging and achievement gaps between minority and majority youth? Multiculturalism, colorblindness and assimilationism assessed. Personality and Social Psychology Bulletin, 45(11), 1603-1618. https://doi.org/10.1177/0146167219838577.

Clegg, S. R., \& Hardy, C. (1999). Studying organization, theory and method. London: SAGE.

Crul, M., Schneider, J., \& Lelie, F. (2013). Superdiversiteit [Superdiversity]. Amsterdam, the Netherlands: VU University Press.

Cummins, J. (2015). How to reverse a legacy of exclusion: Identifying high-impact educational responses. Lanquage and Education, 29(3), 272-279. https://doi.org/10.1080/09500782.2014.994528.

Denis, J. L., Ferlie, E., \& Van Gestel, N. (2015). Understanding hybridity in public organizations. Public Administration, 93(2), 273-289. https://doi.org/10.1111/padm.12175.

Dennis, S. E., \& O'Connor, E. (2013). Reexamining quality in early childhood education: Exploring the relationship between the organizational climate and the classroom. Journal of Research in Childhood Education, 27, 74-92. https://doi. org/10.1080/02568543.2012.739589.

Driessen, G. (2012). De ambities waargemaakt? De ontwikkeling van de onderwijspositie van de doelgroepen van het onderwijsachterstandenbeleid tussen 1995 en 2011. [The ambitions realized? The development of the position of target groups of the educational equity policy in school]. In G. Driessen (Ed.), De doelgroepen van het onderwijsachterstandenbeleid: ontwikkelingen in prestaties en het advies voortgezet onderwijs (pp. 3-35). Nijmegen, The Netherlands: ITS Radboud Universiteit.

Dutch Government. (2005). Wet Kinderopvang [Childcare Act 2005]. Retrieved from https://wetten.overheid.nl/BWBRO 017017/2005-12-29

Dutch Government. (2010). Wet OKE [Childcare Act 2010]. Retrieved from https://wetten.overheid.nl/BWBR001701 7/2010-08-01/1

Dutch Government. (2020). Wet Kinderopvang [Childcare Act 2020]. Retrieved from https://wetten.overheid.nl/BWBRO 017017/2020-01-01

Ernst, T., Mader, M., \& Mierendorff, J. (2014). Gewerbliche Anbieter von Kindertagsbetreuung - eine Systematisierung der Trägerlandschaft [A systematization of the types of Commercial Childcare Providers in Germany]. Zeitschrift für Soziologie der Erziehung und Sozialisation, 34(4), 373-388. https://doi.org/10.3262/ZSE1404373.

European Commission. (2018). Monitoring the quality of early childhood education and care. Retrieved from https://doi. org/10.2766/99057

Gudicha, D. W., Tekle, F. B., \& Vermunt, J. K. (2016). Power and sample size computation for Wald tests in latent class models. Journal of Classification, 33, 30-51. https://doi.org/10.1007/s00357-016-9199-I.

Heckman, J. J. (2011). The economics of inequality: The value of early childhood education. American Educator, 31-35, 47. Retrieved from https://files.eric.ed.gov/fulltext/EJ920516.pdf

Howes, C., Burchinal, M., Pianta, R., Bryant, D., Early, D., Clifford, R., \& Barbarin, O. (2008). Ready to learn? Children's preacademic achievement in pre-Kindergarten programs. Early Childhood Research Quarterly, 23, 27-50. https://doi. org/10.1016/j.ecresq.2007.05.002.

Hox, J. J. (2010). Multilevel analysis. Techniques and applications (2nd ed.). New York: Routledge.

Jenkins, J. M., \& Duncan, G. J. (2017). Do pre-kindergarten curricula matter? The Current State of Scientific Knowledge on Pre-Kindergarten Effects, pp 37-44

Kaga, Y., Bennett, J., \& Moss, P. (2010). Caring and learning together. A cross national study of integration of early childhood education and care within education. Paris: UNESCO. Retrieved from https://education.illinoisstate.edu/downloads/ linc/policies/integratingEarlyCareEducation

Knijn, T., \& Lewis, J. (2017). ECEC: Childcare markets in the Netherlands and England. In B. Unger, D. van der Linde, \& M. Getzner (Eds.), Public or private goods? Redefining Res Publica (pp. 150-172). Cheltenham, England: Edward Elgar Publishing.

Kok, L., Plantenga, J., Schwartz, T., \& Ter Weel, B. (2020). Naar een stabiel stelsel van kinderopvang [Towards a stable system of childcare] SEO-rapport nr. 2020-13. Amsterdam, The Netherlands: SEO University of Amsterdam.

Kremer, M., Bovens, M., Schrijvers, E., \& Went, R. (2014). Hoe ongelijk is Nederland? Een verkenning van de ontwikkelingen gevolgen van economische ongelijkheid [How unequal is The Netherlands? An exploration of the consequences of economic inequality]. Den Haag: Amsterdam University Press.

Kruiter, J., Van der Heyden, K., Jepma, I., \& Donkers, E. (2019). Harmonisatie van peuterspeelzaalwerk en kinderopvang [Harmonization of early childhood education and care]. ]. Utrecht, The Netherlands: Sardes. Retrieved from www.rijks overheid.nl/documenten/rapporten/2019/06/14/onderzoek-stand-van-zaken-harmonisatie-peuterspeelzaalwerk

La Paro, K. M., Hamre, B. K., \& Pianta, R. C. (2011). Classroom assesment scoring system toddler manual. Charlotsville, Virginia: Teachstone.

Leseman, P., Mulder, H., Verhagen, J., Broekhuizen, M., Van Schaik, S., \& Slot, P. (2017). Effectiveness of Dutch targeted preschool education policy for disadvantaged children: Evidence from the pre-COOL study. In H. P. Blossfeld, N. Kulic, J. Skopek, \& M. Triventi (Eds.), Childcare, early education, and social inequality—An international perspective (pp. 173-193). Cheltenham, England: Edward Elgar.

Leseman, P. P. M., \& Slot, P. L. (2020). Universal versus targeted approaches to prevent early education gaps: The Netherlands as case in point. Zeitschrift für Erziehungswissenschaft, 23(3), 485-507. https://doi.org/10.1007/s11618-02000948-8.

Lloyd, E. (2020). Towards a public ECEC system. In C. Cameron \& P. Moss (Eds.), Transforming early childhood in England (pp. 83-99). London: UCL Press.

Lloyd, E., \& Penn, H. (2012). Childcare Markets: Can they deliver an equitable service? Bristol, England: Policy Press, The University of Bristol 
Lower, J., \& Cassidy, D. (2007). Child care work environments: The relationship with learning environments. Journal of Research in Childhood Education, 22(2), 189-204. https://doi.org/10.1080/02568540709594621.

Malik, K. (2015). The failure of multiculturalism: community versus society in Europe. Foreign Affairs, March/April 2015. Retrieved from www.foreignaffairs.com/articles/western-europe/2015-02-18/failure-multiculturalism

Melhuish, E., Ereky-Stevens, K., Petrogiannis, K., Ariescu, A., Penderi, E., Rentzou, K., Tawell, A., Slot, P. L., Broekhuizen, M., \& Leseman, P. (2015). A review of research on the effects of early childhood education and care (ECEC) upon child development. CARE-report D4.1. Oxford, England: Department of Education, University of Oxford. Retrieved from http:// ecec-care.org

Mierendorff, J., Ernst, T., \& Mader, M. (2018). Embedded internationalisation and privilege in German early years provision. In C. Maxwell, U. Deppe, H. H. Krüger, \&W. Helsper (Eds.), Elite education and internationalisation (pp. 121-137). Basingstoke: Palgrave MacMillan. https://doi.org/10.1007/978-3-319-59966-3_8.

Mintzberg, H. (1983). Structure in fives: Designing effective organizations. Englewood Cliffs, New Jersey: Prentice-Hall International Editions.

Mintzberg, H., Ahlstrand, B., \& Lampel, J. (2005). Op strategie-safari. Een rondleiding door de wildernis van strategisch management [Strategy safari]. Schiedam, The Netherlands: Scriptum Management.

Moore, M. H. (2014). Public value accounting: Establishing the philosophical basis. Public Administration Review, 74(4), 465-477. https://doi.org/10.1111/puar.12198.

Naumann, I. (2011). Towards the marketization of early childhood education and care? Recent developments in Sweden and the United Kingdom. Nordic Journal of Social Research, 2, 37-53.

Newberrry, S., \& Brennan, D. (2013). The marketization of early childhood education and care (ECEC) in Australia: A structured response. Financial Accountability \& Management, 29(3), 0267-4424. https://doi.org/10.1111/faam.12018.

Noailly, J., \& Visser, S. (2009). The impact of market forces on child care provisions: Insights from the 2005 Child Care Act in the Netherlands. Journal of Social Policy, 38(3), 477-498. https://doi.org/10.1017/50047279409003109.

Nutt, P. C. (2002). Why decisions fail: Avoiding the blunders and traps that lead to debacles. San Francisco, California: BerrettKoehler Publishers.

OECD (2015). Starting strong IV_Monitoring quality in early childhood education and care. Paris: OECD. Retrieved from www.oecd.org/publications/starting-strong-iv-9789264233515-en.htm

Pavolini, E., \& Van Lancker, W. (2018). The Matthew effect in childcare use: A matter of policies or preferences? Journal of European Public Policy, 25(6), 878-893. https://doi.org/10.1080/13501763.2017.1401108.

Penn, H. (2011). Gambling on the market: The role of for-profit provision in early childhood education and care. Journal of Early Childhood Research, 9(2), 150-161. https://doi.org/10.1177/1476718X10387999.

Penninx, R. (2008). Integration of migrants: Economic, social, cultural and political dimensions. In M. Macura, A. L. MacDonald, \&W. Haug (Eds.), The new demographic regime. Population challenges and policy responses. United Nations Economic Commission for Europe (pp. 137-151). New York: United Nations.

Press, F., \& Woodrow, C. (2018). Marketisation, elite education and internationalisation in Australian early childhood education and care. In C. Maxwell, U. Deppe, H. H. Krüger, \& W. Helsper (Eds.), Elite education and internationalisation (pp. 139-159). Basingstoke, England: Palgrave MacMillan. https://doi.org/10.1007/978-3-319-59966-3_9.

Provan, K. G., \& Kenis, P. N. (2008). Modes of network governance. Journal of Public Administration Research and Theory, 18(2), 229-252.

Putnam, R. D. (2015). Our kids. The American dream in crisis. New York: Simon \& Schuster.

Quinn, J. B., Mintzberg, H., \& James, R. M. (1988). The strategy process. Concepts, contexts and cases. Englewood Cliffs, New Jersey: Prentice-Hall International Editions.

Reardon, S. F. (2011). The widening academic achievement gap between rich and poor: New evidence and possible explanations. In G. J. Duncan \& R. J. Murnane (Eds.), Whither opportunity? Rising inequality, schools, and children's life chances (pp. 91-115). New York: Russell Sage Foundation.

Reynolds, A. J., Temple, J. A., White, B. A. B., Ou, S.-R., \& Robertson, D. L. (2011). Age 26 cost-benefit analysis of the Child-Parent Center Early Education Program. Child Development, 81(1), 279-404. https://doi.org/10.111 1/j.1467-8624.2010.01563.x.

Riederer, B., \& Verwiebe, R. (2015). Changes in the educational achievement of immigrant youth in Western societies: The contextual effects of national (educational) policies. European Sociological Review, 31(5), 628-642. https://doi. org/10.1093/esr/jcv063.

Rözer, J., \& Van de Werfhorst, H. G. (2017). Inequalities in educational opportunities by socioeconomic and migration background: A comparative assessment across European countries. ISOTIS-report D1.2. Amsterdam, The Netherlands: University of Amsterdam. Retrieved from www.isotis.org

Sibley, E., Dearing, E., Toppelberg, C. O., Mykletun, A., \& Zachrisson, H. D. (2015). Do increased availability and reduced cost of early childhood care and education narrow social inequality gaps in utilization? Evidence from Norway. International Journal of Child Care and Education Policy, 9(1), 1-20.

Skelcher, C., \& Smith, S. R. (2015). Theorizing hybridity: Institutional logics, complex organizations, and actor identities. The case of nonprofits. Public Administration, 93(2), 433-448.

Slot, P. L. (2018a). Literature review: Early childhood education and care quality: Relations between structural characteristics at different levels and process quality. Paris: OECD. Retrieved from https://doi.org/10.1787/edaf3793-en

Slot, P. L. (2018). Early childhood education and care in the Netherlands: A shift towards an integrated system aimed at enhancing children's development and learning. In S. Garvis, S. Philipson, \& H. Harju-Luukainnen (Eds.), International teaching, family and policy perspectives. Volume l: Early childhood education in the 21st century: An international perspective (pp. 213-226). London: Routledge.

Slot, P. L., Bleses, D., Justice, L. M., Markussen-Brown, J., \& Højen, A. (2018). Structural and process quality of Danish preschools: Direct and indirect associations with children's growth in language and preliteracy skills. Early Education and Development, 29(4), 581-602

Slot, P., Jepma, Y., Muller, P., Romijn, B., \& Leseman, P. (2018b). Kwaliteit van de Nederlandse kinderdagopvang, peuteropvang, buitenschoolse opvang en gastouderopvang. Gecombineerde metingen 2017-2018. [Quality of Dutch child daycare, 
preschool, afterschool care and host family care. Combined measures 2017-2018]. Utrecht, The Netherlands: Utrecht University/Sardes. Retrieved from www.monitorlkk.nl

Slot, P. L., Lerkkanen, M.-K., \& Leseman, P. P. M. (2015b). The relations between structural quality and process quality in European early childhood education and care provisions: Secondary analyses of large scale studies in five countries. CAREreport D2.2. Utrecht, The Netherlands: Utrecht University. Retrieved from www.ecec-care.org

Slot, P. L., Leseman, P. P. M., Verhagen, J., \& Mulder, H. (2015). Associations between structural quality aspects and process quality in Dutch early childhood education and care settings. Early Childhood Research Quarterly, 33, 64-76. https:// doi.org/10.1016/j.ecresq.2015.06.001.

Slot, P. L., Romijn, B. R. Cadima, J., Nata, G., \& Wysłowska (2018c). Internet survey among staff working in formal and informal (education) sectors in ten European countries. ISOTIS-report D5.3. Utrecht, The Netherlands: Utrecht University. Retrieved from www.isotis.org.

Statistics Netherlands. (2020a). Bevolking, ontwikkeling in gemeenten met 100.000 of meer inwoners. [Population development in municipalities over 100.000 inhabitants] Heerlen, The Netherlands: Centraal Bureau voor de Statisitiek. Retrieved from http://statline.cbs.nl/StatWeb/publication/?VW=T\&DM $=S L N L \& P A=70748 N E D \& D 1=0,2,4,16,18,20,2$ $2,24 \& D 2=a \& D 3=0 \& D 4=a \& D 5=\mid \& H D=090707-1905 \& H D R=T \& S T B=G 4, G 2, G 1, G 3$

Statistics Netherlands. (2020b). Hoeveel mensen met een migratieachtergrond wonen in Nederland? [How many people with migrant background live in The Netherlands?] Heerlen, The Netherlands: Centraal Bureau voor de Statistiek. Retrieved from www.cbs.nl/nl-nl/dossier/dossier-asiel-migratie-en-integratie/hoeveel-mensen-met-een-migratieac htergrond-wonen-in-nederland-

Sylva, K., Ereky-Stevens, K., \& Aricescu, A.-M. (2015). Overview of European ECEC curricula and curriculum guidelines. Carereport D2.1. Oxford, England: University of Oxford. Retrieved from www.ecec-care.org.

Sylva, K., Melhuish, E., Sammons, P., Siraj-Blatchford, I., \& Taggart, B. (2004). The effective provision of pre-school education (EPPE) project: Final report. London: Institute of Education, University of London.

Tsigilis, N., Zachopoupou, E., \& Grammatikoupoulos, V. (2006). Job satisfaction and burnout among Greek early educators: A comparison between public and private sector employees. Educational Research and Review, 1(8), 256-261.

Ünver, Ö. (2019). Accessibility and inclusiveness of early childhood education and care across Europe (doctoral dissertation). Leuven, Belgium: Catholic University of Leuven, Institute for Work and Society.

Ünver, Ö., Bircan, T., \& Nicaise, I. (2018). Perceived accessibility of childcare in Europe: A cross-country multilevel study. International Journal of Child Care and Education Policy, 12(5), 1-30. https://doi.org/10.1186/s40723-018-0044-3.

Van der Werf, W., Slot, P., Kenis, P., \& Leseman, P. (2019). Gevolgen van marktdifferentiatie voor diversiteit, inclusie en kansengelijkheid in kindercentra, een vergelijkende casestudy. Sociologie, 14(1), 1-24.

Van der Werf, W. M., Slot, P. L., Kenis, P., \& Leseman, P. P. M. (2020). Hybrid organizations in the privatized and harmonized Dutch ECEC system: Relations with quality of education and care. Early Childhood Research Quarterly, 53(4), 136-150.

Van Huizen, T. M., Dumhs, E., \& Plantenga, J. (2019). The costs and benefits of investing in universal preschool: Evidence from a Spanish reform. Child Development, 90(3), e386-e406.

Van Huizen, T., \& Plantenga, J. (2018). Do children benefit from universal early childhood education and care? A meta-analysis of evidence from natural experiments. Economics of Education Review, 88, 206-222. https://doi. org/10.1016/j.econedurev.2018.08.001.

Van Lancker, W., \& Van Mechelen, N. (2015). Universalism under siege? Exploring the association between targeting, child benefits and child poverty across 26 countries. Social Science Research, 50(March), 60-75. https://doi.org/10.1016/j. ssresearch.2014.11.012.

Vandenbroeck, M. (2017). Supporting (super)diversity in early childhood settings. In L. Miller, C. Cameron, C. Dalli \& N. Barbour (Eds.), The SAGE handbook of early childhood policy (pp. 403-417). London: SAGE. Retrieved from https:// uk.sagepub.com/en-gb/eur/the-sage-handbook-of-early-childhood-policy/book245964\#contents

Vertovec, S. (2007). Super-diversity and its implications. Ethnic and Racial Studies, 30(6), 1024-1054. https://doi. org/10.1080/01419870701599465.

Yoshikawa, H., Weiland, C., Brooks-Gunn, J., Burchinal, M. R., Espinosa, L. M., Gormley, W. T., Ludwig, J., Magnuson, K. A., Phillips, D., Zaslow, M. J. (2013). Investing in our future: The evidence on preschool education. Chapell Hill, North-Carolina: Frank Porter Graham Center/Society for Research in Child Development. Retrieved from https://fpg.unc.edu/ node/6419

Zaslow, M., Tout, K., Halle, T., Whittaker, J. V., \& Lavelle, B. (2010). Toward the identification of features of effective professional development for early childhood educators, Literature review. Retrieved from www.ed.gov/about/offices/list/opepd/ ppss/reports.html

\section{Publisher's Note}

Springer Nature remains neutral with regard to jurisdictional claims in published maps and institutional affiliations. 